\title{
Manufacturing of Bricks from Soil and Crushed Limestone by Compression
}

\author{
M. O. Amin \\ M. A. M. Khidir \\ A. M. Taher \\ Lecturer \\ Lecturer \\ Assist. Lecturer \\ maherz55@yahoo.com \\ Technical Institute of Mosul
}

\begin{abstract}
The environmental impact due to cement and burnt clay industries are increasing continuously, also cement concrete blocks and burnt clay bricks are increasingly becoming costly due to excessive cost of fuel required to manufacture the cement or burning the clay, while the soil suitable for construction is available everywhere in the world. The paper presents the results of an experimental investigation undertaken at Mosul Technical Institute to assess the potential for unfired compressed earth bricks using locally soil as construction material stabilized with crushed limestone obtained from the waste of masonry factories. The wet soil molded into bricks by manual press known globally as CINVA-RAM, exert high pressure. The press was manufactured locally for the research purposes conducted in the institute. Different percentages of crushed limestone by weight (passing sieve No.8) were added namely $(4,8,12,16$, and 20 $\%$ ) to the soil obtained from $20 \mathrm{~km}$ west of Mosul to reduce its expansiveness if any, and in a trial to improve its characteristics [1]. The results showed increase in compressive strength at $4 \%$ and sharp decrease with higher percentages.
\end{abstract}

Keywords: Unfired compressed earth bricks, CINVA-RAM press, crushed limestone

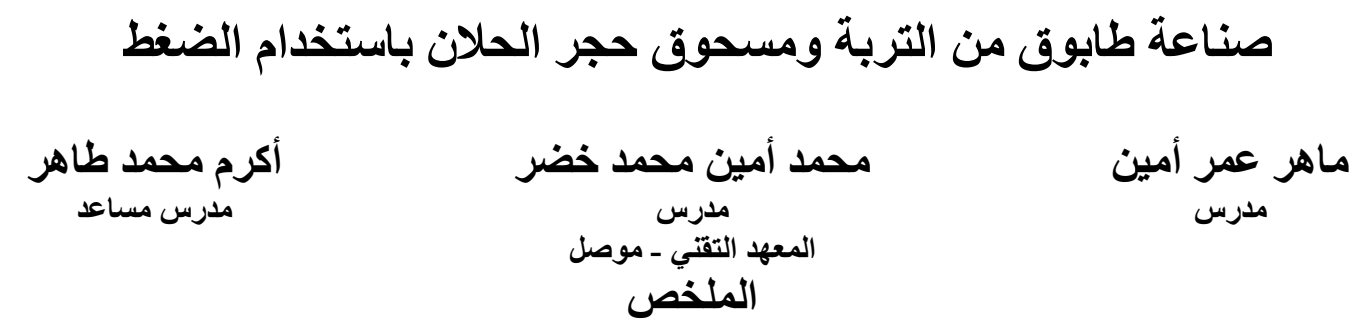

إن التأثيرات البيئية السلبية الناتجة عن استخدام الوقود في صناعة السمنت وفخر الطابوق في تزايد مستمر كنلك فإنان

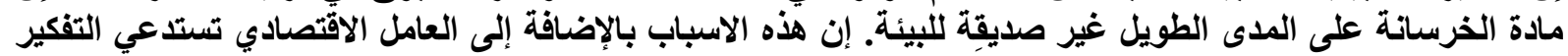

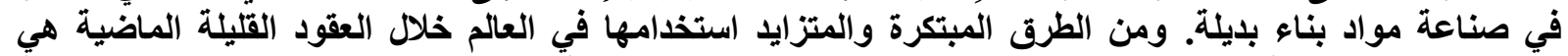

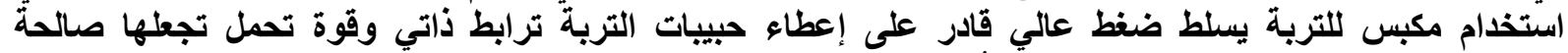

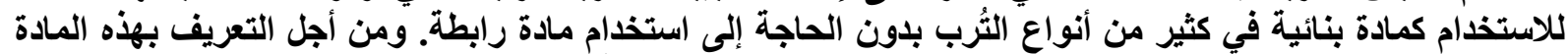

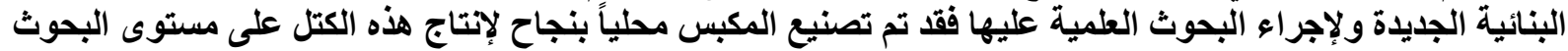

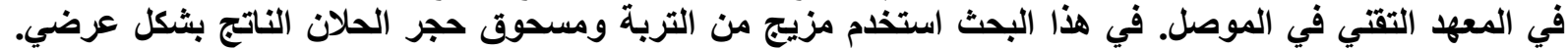

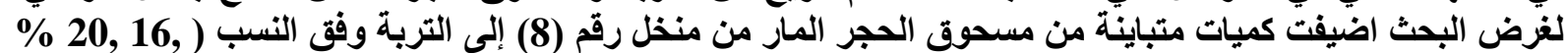
(12, 8, 4, 0

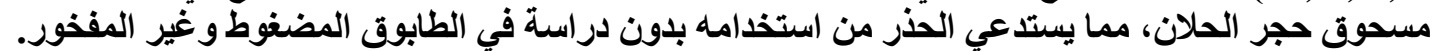

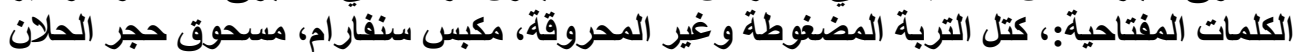

Received: $27-5$ - 2013

Accepted: 19 - 8 - 2013 


\section{1- Introduction}

Compressed Earth Bricks, defined as "masonry elements principally made of raw earth, which are small in size and which have regular and verified characteristic obtained by the static or dynamic compression of earth in a humid state followed by immediate demoulding"[2]. Compressed earth blocks owe their cohesion in a humid state and in a dry state essentially to the clay fraction within the earth; an additive can, however, be added to the earth to improve or enhance particular characteristics of the product [3-9]. Growing concern and interest about environmental and ecological issue increased the used of earth as a building material. In comparison with another building material, compressed earth block offered numbers of advantages. It increases the utilization of local material and reduces the transportation cost as the production is in situ, makes quality housing available to more people. Good strength, insulation and thermal properties, less carbon emission and embodied energy in the production phase, create extremely low level of waste, cause no direct environmental pollution during the whole life cycle[16]. Earth brick also have the ability to absorb atmospheric moisture which resulted create healthy environment inside a building for its occupant. According to [11], unfired clay bricks have "14\% of the embodied energy of fired bricks and $25 \%$ of the embodied energy of concrete blocks."

One of the drawbacks using earth alone as a material for construction is its durability which is strongly related to its compressive strength [8][20][21]. Obtaining a durable material would need a treatment which would result in a sufficient mechanical strength as well as low sensitivity to water. The most common methods employed for the stabilization of clayey soils are cement and lime stabilization [3-9].

In another study [12], an attempt to improve strength and water absorption of blocks stabilized not only by cement but also by lime, bitumen and gypsum, and observes that gypsum and bitumen blocks fail the erosion test; cement \& lime addition increase strength and reduce water absorption.

In the present work, we have tried to examine the properties of earth bricks for certain type of soil near Mosul by the addition of crushed limestone.

\section{2- Materials}

\section{2-1 Limestone}

Limestone is the most widely rock in Iraq and particularly in Mosul area, where it can be extensively used in constructional activities. Limestone consists essentially of calcium carbonate, with which there is generally some magnesium carbonate and siliceous matter such as quartz grains. In order to determine the influence of crushed limestone content as a stabilizer for the mechanical properties of unfired clay bricks, several blends have been used with $(0,4,8,12,16$ and $20 \%)$.

\section{2-2 Soil}

The soil used in the investigation were taken from location $20 \mathrm{~km}$ to the west of Mosul city which is chiefly of silt and clay soil, the soil have the following properties L.L. (37) \%, P.I. (16) \%. Thus the soil is classified as (CL) according to the Unified Classification System and described as "Inorganic clay of low plasticity". The percentage of clay size particles $(\leq 2 \mathrm{~m})$ is $28 \%$. The specific gravity (Gs) is 2.72 . The linear shrinkage (8.0) \%. The soil was mixed with different amounts of crushed limestone passing sieve No.8, namely (0, 4, 8, 12, 16 and 20\%) and a compacting stress sufficient to produce $1.88 \mathrm{gm} / \mathrm{cm}^{3}$ wet density. 


\section{3- Testing Of Materials}

\section{3-1 Atterberg Limits}

The consistency limits of the treated soil were determined after being mixed with $(4,8,12,16$ and 20\%) of the crushed limestone. The results are presented in Table (1). It can be noticed that the liquid and plasticity indices decreased with the increase of the added crushed stones.

Table (1) Atterberg limits of treated and untreated soil

\begin{tabular}{|c|c|c|c|c|c|c|}
\hline Crushed Limestone passing sieve No.40 & 0 & 4 & 8 & 12 & 16 & 20 \\
\hline Liquid Limits (L.L) \% & 37 & 33 & 29 & 25 & 23 & 20 \\
\hline Plastic Limits (P.L) \% & 21 & 20 & 18 & 16 & 15 & 13 \\
\hline Plasticity Index (P.I) \% & 16 & 13 & 11 & 9 & 8 & 7 \\
\hline
\end{tabular}

\section{3-2 Linear shrinkage}

Shrinking of earth blocks when drying out is disadvantages, if they are to be used as building materials. According to [14], shrinkage depends on the type and quantity of clay; Table (2) show that the linear shrinkage reduced from 8.0 to $6.6 \%$ by the addition of the crushed Lime stones CLS. This addition leads to improvement of soil workability, but not to an increase in strength [15].

Table 2. Linear shrinkage of treated and untreated soil

\begin{tabular}{|c|c|c|c|}
\hline Type of soil & Shrinkage (mm) & Total Length & Percentage \\
\hline Soil & 48 & 600 & 8.0 \\
\hline Soil + 4\% CLS & 46 & 600 & 7.6 \\
\hline Soil + 8\% CLS & 43 & 600 & 7.1 \\
\hline Soil + 12\% CLS & 41 & 600 & 6.8 \\
\hline Soil + 16\% CLS & 40 & 600 & 6.6 \\
\hline
\end{tabular}

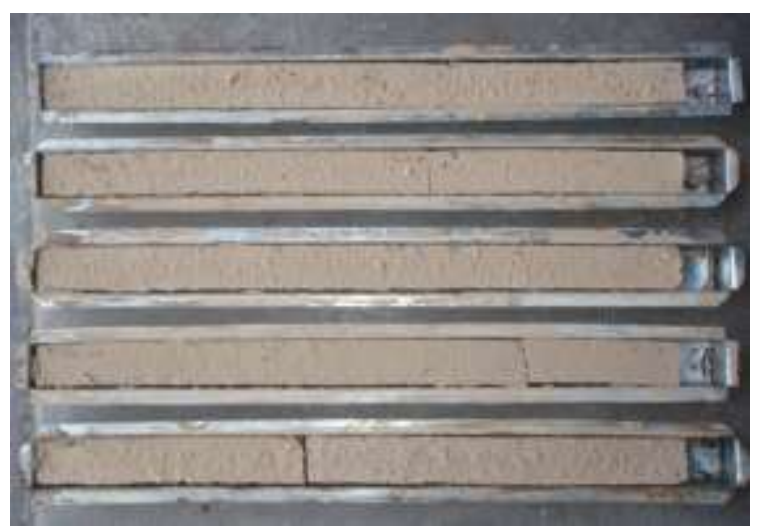

Figure.1 Shrinkage Testing moulds

\section{3-3 Grain Size Analysis:}

Table (3) describes the analysis result. It can be shown that the clay size particles decreased with the increase of crushed Limestone addition, while the percent of silt size particles increased. 
Table (3) Comparison of the grain-size analysis results

\begin{tabular}{|c|c|c|c|}
\hline \% Crushed Limestone passing Sieve No. 8 & \% Clay & \% Silt & \% Sand \\
\hline 0 & 28 & 51 & 21 \\
\hline 4 & 25 & 53 & 22 \\
\hline 8 & 22 & 55 & 23 \\
\hline 12 & 19.5 & 57.5 & 23 \\
\hline 16 & 16.5 & 60.5 & 23 \\
\hline 20 & 14 & 63 & 23 \\
\hline
\end{tabular}

(Walker, 1996) states that clay contents of between $5 \%$ and $20 \%$ are considered suitable for earth block production. The results indicate that the clay proportion $(20 \%)$ is within the recommended limits required for production of compressed soil bricks. The clay presence is important in the sense that, clay is responsible for the bonding effect amongst the soil particles. The soil also contains sufficient amounts of course fraction, i.e. $20 \%$ sand by proportion, this amount is sufficient to limit shrinkage of blocks when drying out [14].

\section{3-4 Modified Compaction Test:}

The modified proctor test was conducted on soil samples treated with $(0,4,8,12,16$ and $20 \%$ ) of crushed limestone. The samples were compacted at different moisture contents, to obtain the moisture-density relationship. The results are summarized in Table (4). To clarify the difference due to the treatment. It can be noticed that the dry density $(\gamma d)$ increases with the amount of crushed stone added up to $4 \%$, and then it tends to decrease. So, it can be said that $(4 \%)$ addition is the optimum that gives the maximum density.

Table (4) The Modified Compaction Test Results.

\begin{tabular}{|c|c|c|c|c|c|c|}
\hline \% Crushed Limestone passing sieve No. 8 & 0 & 4 & 8 & 12 & 16 & 20 \\
\hline Max. Dry Density $(\gamma \mathrm{d}) \mathrm{kN} / \mathrm{m}^{2}$ & & 1.69 & 1.68 & 1.65 & 1.66 & 1.65 \\
\hline Optimum Moisture Content (O.M.C) & 20 & 20 & 19 & 18.2 & 18 & 18.5 \\
\hline
\end{tabular}

\section{4- Cinva-Ram Press}

The compressed earth block is the modern descendent of the moulded earth block. the turning point in the use of presses and in the way in which compressed earth blocks were used for building and architectural purposes came only with effect from 1952, following the invention of the famous little CINVA-RAM press, designed by engineer Raul Ramirez at the CINVA centre in Bogota, Columbia. This was to be used throughout the world. With the 70s and 80s there appeared a new generation of manual, mechanical and motordriven presses, leading to the emergence today of a genuine market for the production and application of the compressed earth block[18].The press was manufactured locally for the research

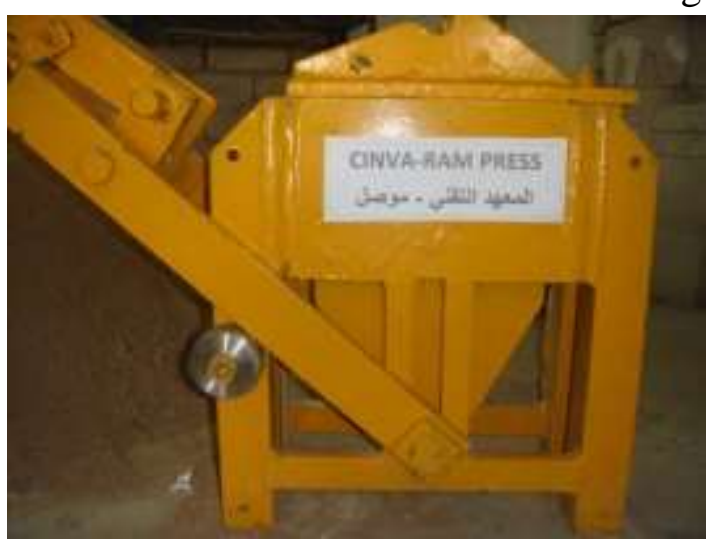

Figure.2 CINVA-RAM press purposes conducted in the Technical Institute of 
Mosul as shown in Fig.2, producing bricks with dimensions of $(290 \times 140 \times 100 \mathrm{~mm})$ as shown in Figs.3\&4.

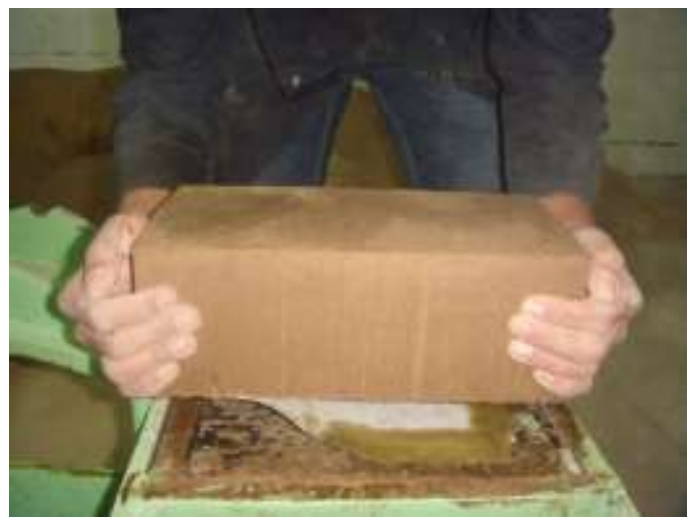

Figure.3 Ready brick for curing

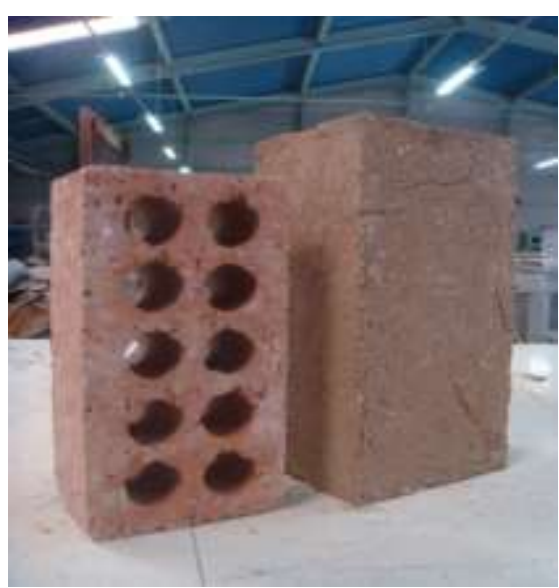

Figure.4 Laboratory-produced unfired brick compared with fired brick

\section{5- Bricks Preparation}

The "qualified" soil is dried by spreading it in an open space, larger granules of soil, such as lumps and gravel are removed by sieving with $4 \mathrm{~mm}$ sieve; the required quantity of soil was weighted. The ratios of crushed limestone used in the various mixtures investigated were respectively $0,4,8,12,16$ and $20 \%$ by weight of semi dry soil. Four ratios of mixing water were used for each of the above soil-crushed limestone mixes 12, 16, 20 and 24\%. The mixing was done by small concrete mixer and continued sufficient time to get a homogeneous mixture of constituents. The mixture was then transferred to a CINVA-RAM press for molding. The ejected blocks, see Fig.3, were then placed in a yard and wrapped tightly with plastic cover to preserve the moisture for three days and then damp cured for the maturity about two weeks. After one month the blocks were tested for the unit weight, compressive strength, flexural strength, shrinkage and absorption. Four specimens for each mix were tested for compressive strength and two specimens for flexural strength.

\section{6- Test of Bricks and Discussion of Results}

A series of tests are carried out to determine the unit weight, the compressive strength, flexural strength and water absorption of brick samples.

\subsection{Compressive Strength Test}

Since there is no standard testing for unfired compressed bricks, the compressive strength test for the brick was held according to the ASTM: C67 and that was representing by applying the bricks in their dry curing condition to the test. The compressive strength of the specimen was calculated from the following equation:

$$
C=W / A
$$

The compressive strength $C$ in $\mathrm{MPa}$ was calculated by dividing the breaking load $W$ (maximum load) in Newton's by the average of

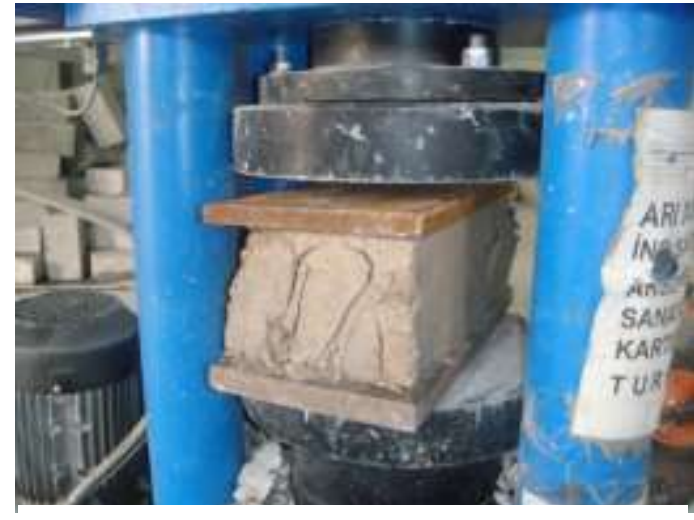

Figure.5 Appearance of failure after compressive test 
the gross areas $A$ of the upper and lower bearing surfaces of the specimen in square millimeters.

\subsubsection{Effect of Mixing Water content on Compressive Strength}

The water content more convenient for molding the bricks is function of the soil type. To obtain compressed bricks of quality with a certain earth, it is necessary to establish the ideal percentage of water and amount of material to be put in the mold of the press, through an optimization process. The water content is not usually the same obtained by the Proctor test where the maximum density is reached by a dynamic compaction. In the press, the compaction is almost static, what gives a certain difference. Figure 6, shows that the compressive strength of samples tested increases

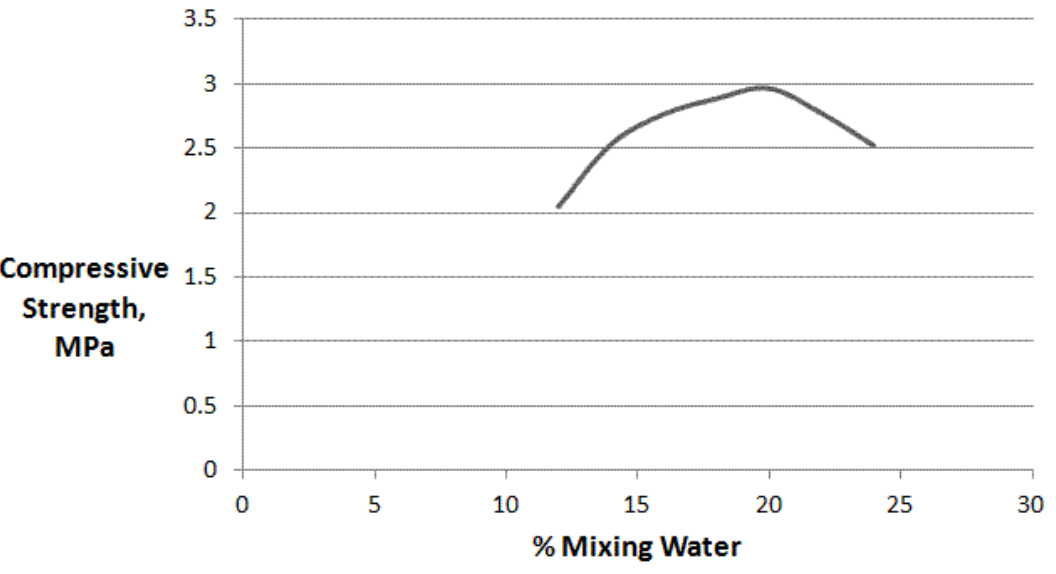

Figure (6): Effect of Mixing water on Compressive Strength with increasing of mixing water content and the optimum at about $20 \%$. It shows clearly that the compressive strength increases with increasing of mixing water until $20 \%$, which is the optimal mixing water content and then decreases rapidly.

\subsubsection{Effect of Crushed limestone on compressive strength}

Figure.7 shows that the compressive strength of samples tested increases due to addition of about $3-4 \%$ crushed limestone and then rapidly decreases. Increasing of crushed limestone from $4 \%$ to $15 \%$ has resulted in more than $50 \%$ decrease in strength. This graph shows that all the bricks lose strength as the crushed limestone content increases.

\subsection{Flexural Strength Test}

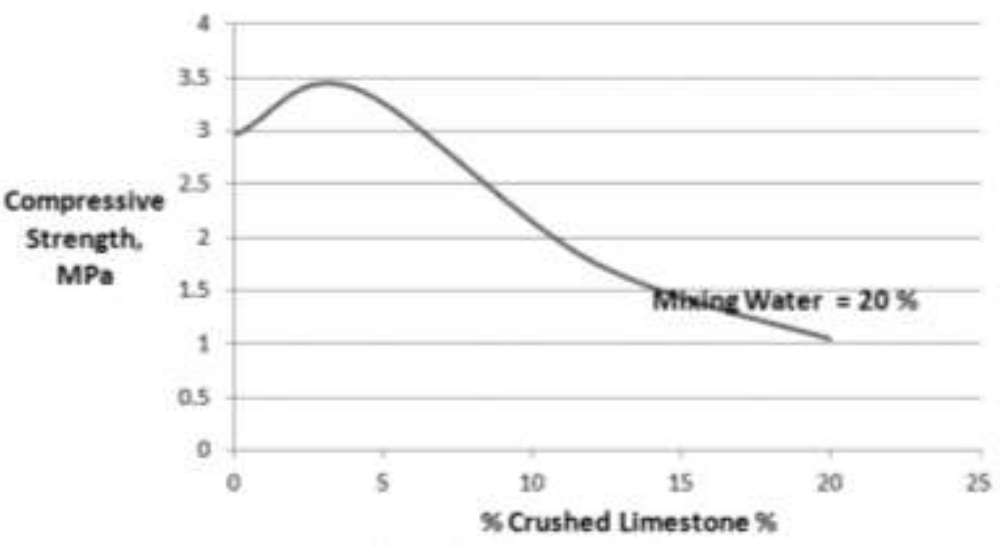

Figure (7): Effect of LS on Compressive Strength

Universal testing machine was used to carry out the flexural strength test. The modulus of rupture of each specimen was calculated by using the following formula:

$\mathrm{fr}=3 \mathrm{PL} / 2 \mathrm{bd}^{2}$

Where: 
$\mathrm{fr}=$ modulus of rupture of the specimen at the plane of failure, $\mathrm{MPa}$,

$\mathrm{P}=$ mid-span concentrated load indicated by the testing machine,

$\mathrm{L}=$ distance between the supports, $\mathrm{mm}$,

$\mathrm{b}=$ net width of the specimen at the plane of failure, $\mathrm{mm}$,

$\mathrm{d}=$ depth of the specimen at the plane of failure, $\mathrm{mm}$.

This formula is used only for measuring the strength of the block, but a minimum acceptable load can also be set. For example, the tested block should withstand a load of 15 blocks to be acceptable [18].

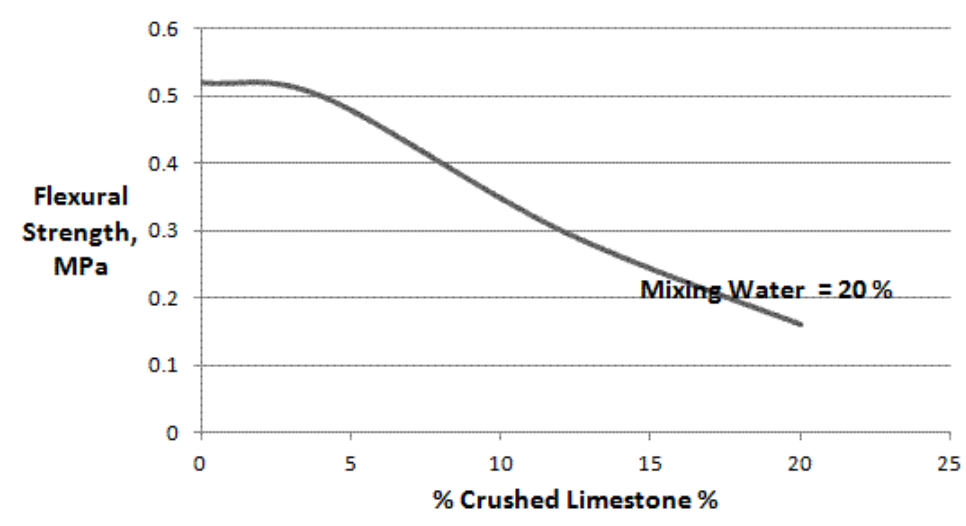

Figure (8): Effect of LS on Flexural Strength

\subsection{Clay Brick Densities}

Commonly, most researchers found that the density of compressed earth bricks is within the range of 1500 to $2000 \mathrm{~kg} / \mathrm{m}^{3}$ [16]. Density of the compressed earth brick is consistently related to its compressive strength and compactive force applied during production. The dry density is largely a function of the constituent material's characteristics, moisture content during pressing and the degree of compactive load applied. The higher density obtained due to compaction significantly increases the compressive strength of the blocks, as well as their resistance to erosion and to damage from water. The unit weights of brick samples are obtained by dividing the mass of the bricks by their overall volume. The average wet density of the units produced as part of this research was $1880 \mathrm{~kg} / \mathrm{m}^{3}$. Whereas the general specification (given for a standard block) gives the following limits:

Dry: minimum: $1700 \mathrm{~kg} / \mathrm{m}^{3}$; recommended: $2000 \mathrm{~kg} / \mathrm{m}^{3}$.

Freshly molded: minimum: $1870 \mathrm{~kg} / \mathrm{m}^{3}$; recommended: $2200 \mathrm{~kg} / \mathrm{m}^{3}$.

Clearly, the bricks produced just satisfy the minimum standard requirement for freshly molded and does not satisfy the minimum dry density.

\subsection{Water Absorption}

The absorption capacity of earth blocks gives a general idea on the presence and importance of voids. As the density of soil increased, its porosity is reduced and less water can penetrate it [19]. Water absorption is a function of clay and compacting stress and usually related with the strength and durability of earth bricks and therefore it is important to determine the rate of water absorption of earth bricks. High rate of water absorption of a specimen may cause swelling of clay fraction and resulting in losing strength with time. The test consists of immersing the soil samples in water and measuring the increase in weight after 24 hours. The absorption is evaluated in dry weight percentage. Water absorption test for the samples was failed due to excessive deterioration as shown in Figure.9. 


\section{7- Conclusions}

In this paper, the influence of adding crushed limestone on the mechanical and physical properties of the unfired compressed soil bricks was presented. The following main conclusions can be drawn from this study:

1. The index properties of the soil were changed by the addition of the crushed stone towards silty characteristics.

2. Compressive strength of unfired compressed soil bricks were improved by the presence of small percentages of crushed limestone not exceeding $4 \%$.

3. Adding more crushed limestone causing rabid decrease of strength, for example at about $15 \%$ the strength decreases to about half.

4. The lower compressive strength at high percentages of crushed limestone can be attributed to insufficient cohesion between clay

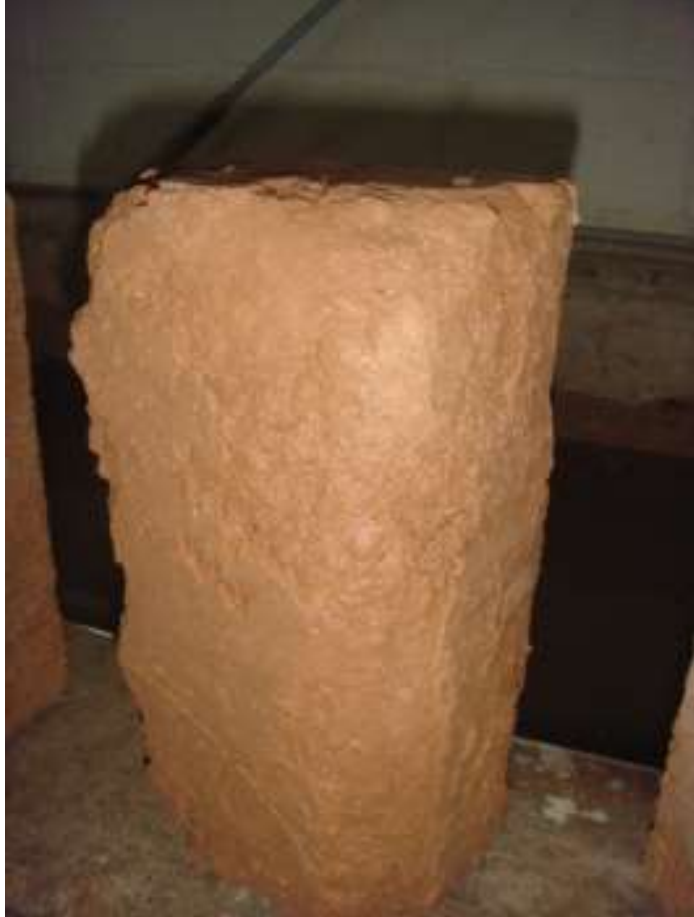

Figure (9): Appearance of brick after saturation test particles and the surrounding soil.

5. It is necessary to make thorough studies before adding crushed limestone to the soil for making unfired compressed bricks.

6. The reduction of the index properties towards less plastic nature indicates that there will be reduction in the swelling potentials.

\section{8- References}

[1]- Siham I. Al-Azzo, "Treatment of Expansive Clayey Soil in AL-Wahda District at Mosul City with Crushed Limestone". Iraqi Journal of Earth Sciences, Vol. 9, No. 2, pp. 1-10, 2009

[2]-Compressed Earth Blocks: Standards., 1998. Brussel, Belgium: CDI and CRATerreEAG Publication.

[3]- E.A.Adam (2001) "Compress Stabilized Earth Block Manufacture in Sudan."

[4]- Gooding,D.E.M (1993) "Improved processes for the production of soil cement building blocks", University of Warwick.

[5]- Peter. W and Trevor. S "Properties of some cement stabilised compressed earth blocks and morters/Materials and Structures", Vol.30, November 1997, pp 545-551

[6]- Smith, R.G., "Building with soil-cement bricks", Building Research and Practice (March/April 1974) pp. 98-102.

[7]- Heathcote, K., "Compressive strength of cement stabilized pressed earth blocks", Building Research and Information 19 (2) (1991) pp. 101-105.

[8]- Walker, P.J., "Strength, durability and shrinkage characteristics of cement stabilized soil blocks", Cement \& Concrete Composites 17 (1995) pp. 301-310.

[9]- Bell, F.G. 1996. "Lime Stabilization of Clay Mineral and Soil".Eng. Geol. 42, Dept. of Geol. and App Geol. University of Natal, South Africa, pp. 223-237. 
[10]- Oliver, M. and El Gharbi, Z., "Sisal fibre reinforced soil block masonary", Proceedings of the Fourth International Masonry Conference, London, October, 1995 (British Masonry Society, Stock-on-Trent, 1995) pp. 55-58.

[11]- Heath, Andrew. "Unfired clay bricks." Copyright Greenspec 2010. Web. January 22, 2012.

[12]- Ozkan, E., Al-Herbish, M. S., "An Experimental Study of the Critical Properties of Pressed and Stabilized Earth Bricks". Architectural Science Review, Vol. 38, pp. 59-73, 1995

[13]- Al-Layla, M.T. and Al-Ashou, M.O. 1985. "Swelling Properties of Mosul Clay". Proc. Iraqi Conf. on Eng., Baghdad-Iraq, pp. 18-23.

[14]- Minke, G., "Earth Construction Handbook". WIT Press, Boston, 2000.

[15]- Bell, F.G., 1996. "Lime stabilization of clay minerals and soils". Engineering Geology, 42(4): 223-237.

[16]- Fetra, V. R., and et al "Preliminary Study of Compressed Stabilized Earth Brick (CSEB)" Australian Journal of Basic and Applied Sciences, 5(9): 6-12, 2011.

[17]- Walker, P., "Specifications for Stabilized Pressed Earth Blocks". Masonry International, 10, (1), pp. 1-6, 1996.

[18]- Vincent Rigassi, "COMPRESSED EARTH BLOCKS: Manual of production" by CRATerre-EAG.

[19]- Houben, H., Guillaud, H., (CRATerre), "Earth Construction" (1984). Primer Brussels, CRATerre / PGC / CRA / UNCHS / AGCD.

[20]- Venkatarama Reddy BV, "Sustainable materials for low carbon buildings".

[21]- Venkatarama Reddy BV, Jagadish KS. Influence of soil composition on the strength and durability of soil-cement blocks. Indian Concret J 1995;69:517-24. 